\title{
Evaluation of Egg Quality of Japanese Quail in Different Housing Systems
}

\author{
Hesham H. Mohammed ${ }^{*}$ and Heba S.A. Gharib \\ Veterinary Public Health Department, Faculty of Veterinary Medicine, Zagazig University, \\ 44511, Egypt
}

\begin{abstract}
A total of 135 birds of Japanese quails at $5^{\text {th }}$ week of age were divided randomly into three groups housed in galvanized metal cages, pens covered with fine and coarse sawdust for the $1^{\text {st }}$, $2^{\text {nd }}$ and $3^{\text {rd }}$ groups, respectively. The results revealed that egg length, egg shape index, shell weight, shell ratio and egg thickness were significantly affected by housing system. The egg produced in fine sawdust group had the highest egg shape index $(82.75 \%)$, shell weight $(1.69 \mathrm{~g})$, shell ratio $(15.88 \%)$ and shell thickness $(0.27 \mathrm{~mm})$ with lowest egg length $(29.98 \mathrm{~mm})$ in fine sawdust group when compared with other systems. On the other hand, egg weight (11.99 g), egg surface area $\left(22.91 \mathrm{~cm}^{2}\right)$, egg width $(25.86 \mathrm{~mm})$ was higher in the cage system with no significant differences. Moreover, the most of internal egg quality was significantly affected by different housing systems, while there were no significant differences in albumin ratio and width, yolk weight and ratio. Threfore, the egg quality (internal and external traits) was better in cage system and deep litter system with fine sawdust in comparison to the deep litter system with coarse sawdust.
\end{abstract}

Keywords: Housing system, Quail, Egg quality.

\section{Introduction}

The Japanese quail (Coturnix japonica) is one of the best birds using in researches that characterized by easy maintenance, short generation interval and high egg production [1]. Moreover, the productivity and quality of the eggs in quails are important in an economical breeding and also for the propagation of the flocks. Before, 2000 B.C. the Egyptians are known the quails and represented it as "W" in the alphabet [2]. Eggs of most bird species may have similarities in nutritional composition and potential food usage [3]. However, information on egg quality characteristics and utilization of egg for food and other purposes has been limited mostly to chicken eggs. The egg quality plays the role in the economy, where poor quality causes economic losses in egg industry [4]. Furthermore, the changes in external quality correlated with internal quality of quails [5] and layers [6], hence, cause the main change in egg production [7]. The housing system is an external factor that influences both the performance of hens and the egg quality [8]. There were several studies have been conducted on the effects of different housing systems, such as conventional cage, enrichedcage and outdoor systems on external and internal egg quality characteristics of hens $[9,10]$. However, there are limited studies evaluating the differences among housing systems for egg quality traits of quails. The findings of Alam et al. [11] showed that egg production for quails reared in battery cages was higher than that reared on litter floor, while Arumugam et al. [12] found that the fertility level for Japanese quails was not affected by system of rearing. Because of the growing interest in the consumption of quail eggs in our country and due to the lack of recent investigations in this direction, the current study was conducted to evaluate the effect of housing system on egg quality of Japanese quail (Coturnix japonica) and the correlation between external and internal quality traits.

\section{Material and methods}

A total number of 135 female quails (weight 150-160 g) of five weeks old were collected from Faculty of Agriculture, Zagazig University, Egypt. They were classified into three groups each of 45 birds; group housed in galvanized metal cages, group housed in pens covered with fine sawdust and group housed in pens covered with coarse sawdust. Each group was divided into three replicates (each of 15 birds) and the available area per quail was 0.06 $\mathrm{m}^{2} /$ bird. Laying quails in all groups were fed identical commercial feed mixtures (Table 1),

*Corresponding author email: (heshamvet_hosny@yahoo.com), Veterinary Public Health Department, 102 Faculty of Veterinary Medicine, Zagazig University, 44511 Egypt. 
which was formulated to meet the nutrient requirements of quails [13], which containing of $20 \%$ crude protein, $2.5 \%$ calcium and 11.93 $\mathrm{MJ} / \mathrm{kg}$ metabolized energy that fed two times daily (7 am and $5 \mathrm{pm}$ ). Feed and water were provided ad-libitum. The daily light duration consisted of 14 hours light from natural light with 10 hours dark until the end of the study. Ninety quail's eggs (from the $8^{\text {th }}$ until the $10^{\text {th }}$ weeks of age) were collected (30 eggs from each group). The Sartorius 1202 MP balance has been used to measure the weight $(\mathrm{g})$ of whole egg, albumen, yolk and egg shell weight, while electronic digital caliper was used for calculating the whole egg length, width, shell thickness, albumen height and width, yolk height and width ( $\mathrm{mm})$ [4]. Ahmed et al. [14] calculated the egg shape index through the following equation: egg width/egg length $\mathrm{x}$ 100. As well as the egg shell ratio was calculated, shell weight/egg weight $\mathrm{x} 100$. Moreover, Sezer [15] calculated the egg surface area $\left(\mathrm{cm}^{2}\right)$ as the following: $3.9782 \mathrm{~W}$ 0.7056 , where $\mathrm{W}=$ egg weight. The albumen and yolk ratios were calculated using the individual weight of each egg and the weight of their components [8]. Haugh Unit $=100 \mathrm{log}$ (albumen height $+7.57-1.7 \mathrm{x}$ egg weight ${ }^{0.37}$ [16].

One way ANOVA used for analysis the data through a SAS program [17]. Duncan's tests were conducted to determine the differences among the means [18]. The correlation estimates between external and internal quality were done using Pearson correlation.

Table 1: Ingradiants of the experimental diet $(\mathrm{kg} / 100 \mathrm{~kg})$

\begin{tabular}{lccr}
\hline Ingredient & Kg & Calculated analysis & \\
\hline Yellow corn & 65 & Metabolized energy & $11.93 \mathrm{MJ} / \mathrm{kg}$ \\
Soybean meal & 20 & Crude protein & $20 \%$ \\
Corn gluten & 5.2 & Calcium & $2.5 \%$ \\
Calcium carbonate \& phosphate & 2.1 & & \\
Soybean oil & 0.2 & \\
Premix and common salts & 0.7 & \\
Other feed additive & 0.6 & \\
\hline
\end{tabular}

\section{Results and Discussion}

The changes of egg quality in housing systems (cage, deep litter with fine sawdust and deep litter with coarse sawdust) were showed in Tables 2 and 3, respectively. The results revealed significant differences in most of the external and internal quality. Moreover, the results revealed a significant correlation among the most quality traits (Table 4). Egg weight is an important parameter for overall egg quality and economics [19]. From the obtained results (Table 2), it is clear that egg weight, egg surface area and egg width were higher in cages than other groups, but the differences did not reach the significance. Leyendecker et al. [20] stated that egg weight was higher in cage systems than in floor systems or free-range systems. Nerveless, in other studies, heavier eggs were found in litter systems than in cages [21,22]. In the present study, egg length from the cage system was significantly higher than those from the other systems, while the egg shape index was the highest in floor system with fine sawdust with significant differences [19]. The egg shape index was higher in cage-system eggs than in the litter system eggs [23]. Jana et al. [24] mentioned that the highest shape index was detected in a cage than litter system. Otherwise, these results disagreed with others $[25,26,27]$ who found that housing system did not affect the egg shape index. 
Table 2: Effect of the different housing systems on external egg quality traits of Japanese quail

\begin{tabular}{|c|c|c|c|c|}
\hline \multirow{2}{*}{ External egg quality } & \multicolumn{3}{|c|}{ System of housing } & \multirow{2}{*}{ P-Values } \\
\hline & $\begin{array}{l}\text { Deep litter with } \\
\text { coarse sawdust }\end{array}$ & $\begin{array}{l}\text { Deep litter with fine } \\
\text { sawdust }\end{array}$ & Cage system & \\
\hline Egg weight $(g)$ & $10.96 \pm 0.13$ & $10.86 \pm 0.82$ & $11.99 \pm 0.57$ & 0.331 \\
\hline Egg surface area $\left(\mathrm{cm}^{2}\right)$ & $21.51 \pm 0.20$ & $21.30 \pm 1.08$ & $22.91 \pm 0.75$ & 0.289 \\
\hline Egg width $(\mathrm{mm})$ & $24.7 \pm 0.47$ & $24.80 \pm 0.47$ & $25.86 \pm 0.45$ & 0.162 \\
\hline Egg length (mm) & $31.25 \pm 0.54^{\mathrm{ab}}$ & $29.98 \pm 0.23^{\mathrm{b}}$ & $32.42 \pm 0.59^{\mathrm{a}}$ & 0.005 \\
\hline Egg shape index $(\%)$ & $79.05 \pm 0.81$ & $82.75 \pm 1.6$ & $79.84 \pm 0.92$ & 0.079 \\
\hline Shell weight $(\mathrm{g})$ & $1.08 \pm 0.03^{\mathrm{b}}$ & $1.69 \pm 0.07^{\mathrm{a}}$ & $1.66 \pm 0.08^{\mathrm{a}}$ & 0.000 \\
\hline Shell ratio $(\%)$ & $9.86 \pm 0.25^{\mathrm{c}}$ & $15.88 \pm 0.79^{\mathrm{a}}$ & $13.89 \pm 0.32^{\mathrm{b}}$ & 0.000 \\
\hline Shell thickness (mm) & $0.20 \pm 0.01^{\mathrm{b}}$ & $0.27 \pm 0.01^{\mathrm{a}}$ & $0.26 \pm 0.01^{\mathrm{a}}$ & 0.000 \\
\hline
\end{tabular}

${ }^{\mathrm{abc}}$ Means within the same row having different superscripts were significantly different at $\mathrm{P}<0.05$.

Table 3: Mean $\pm \mathrm{SE}$ of internal egg quality of quails in relation to different housing systems

\begin{tabular}{lcccc}
\hline \multirow{2}{*}{ Internal egg quality } & \multicolumn{3}{c}{ System of housing } \\
\cline { 2 - 4 } & $\begin{array}{c}\text { Deep litter with } \\
\text { coarse sawdust }\end{array}$ & $\begin{array}{c}\text { Deep litter with fine } \\
\text { sawdust }\end{array}$ & Cage system & \\
\hline Albumin weight (g) & $5.95 \pm 0.79^{\text {ab }}$ & $5.57 \pm 0.20^{\mathrm{b}}$ & $6.31 \pm 0.28^{\mathrm{a}}$ & 0.051 \\
Albumin ratio (\%) & $54.32 \pm 0.89$ & $52.46 \pm 2.05$ & $52.80 \pm 1.54$ & 0.676 \\
Albumin height (mm) & $5.41 \pm 0.15^{\mathrm{a}}$ & $5.15 \pm 0.16^{\mathrm{ab}}$ & $4.86 \pm 0.17^{\mathrm{b}}$ & 0.084 \\
Albumin width (mm) & $41.21 \pm 0.99$ & $36.35 \pm 0.71$ & $40.71 \pm 0.96$ & 0.271 \\
Yolk weight (g) & $3.93 \pm 0.13^{\mathrm{b}}$ & $3.59 \pm 0.63$ & $4.02 \pm 0.33$ & 0.750 \\
Yolk ratio (\%) & $35.81 \pm 0.85$ & $31.56 \pm 0.81$ & $33.31 \pm 0.56$ & 0.305 \\
Yolk height (mm) & $9.39 \pm 0.25^{\mathrm{ab}}$ & $9.25 \pm 0.20^{\mathrm{b}}$ & $9.94 \pm 0.09^{\mathrm{a}}$ & 0.047 \\
Yolk width (MM) & $21.09 \pm 0.39^{\mathrm{b}}$ & $21.91 \pm 0.36^{\mathrm{ab}}$ & $22.99 \pm 0.37^{\mathrm{a}}$ & 0.005 \\
Haugh unit & $94.64 \pm 0.79^{\mathrm{a}}$ & $93.53 \pm 0.98^{\mathrm{ab}}$ & $91.14 \pm 1.11^{\mathrm{b}}$ & 0.049 \\
\hline
\end{tabular}

${ }^{\mathrm{abc}}$ Means within the same row having different superscripts are significantly different at $\mathrm{P}<0.05$.

Egg shell quality is important for economic reasons. Previous studies compared traditional cages with other housing systems and observed thicker egg shells in aviary and barn systems [25]. In the present study, housing systems had a significant effect in egg shell quality, where shell weight, ratio and thickness were the highest in litter system with fine sawdust. These results were disagreed with others $[9,19,23]$ who stated that the housing systems did not affect the egg shell quality. Englmaierova et al. [8] compared different housing systems and observed higher shell ratio in aviary eggs than in cages and litter system eggs. El-Sheikh et al. [28] mentioned that there was non significant effect of the housing system (cage \& floor) on shell percentage and shell thickness with or without membranes.

Data presented in Table (3) showed the effect of housing system on the internal egg quality of Japanese quails. The eggs in cage system had the highest albumin weight, yolk weight and height, while it had the lowest albumin height and Haugh unit in comparison to other systems. On the other hand, Bilgehan et al. [19] stated that yolk weight, albumen weight, albumen index and the Haugh unit was higher in the floor system, but were similar to the conventional and enriched cage systems. Samiullah et al. [29] and Tůmova et al. [30] reported that the eggs Haugh unit in a conventional-cage system was higher than those in a free-range system. However, in other studies there were no differences between housing systems regarding Haugh unit in Japanese quails [23,27]. On the contrary, there were no significant differences in other internal egg quality, which agreed with Abdel-Fatah [31] who found no significant differences in the egg quality between deep-litter system and battery cages.

In the present study, the correlation between internal and external egg quality (Table 4), revealed a positive correlation of egg weight and egg surface area with albumen weight $(0.737$ and 0.740$)$, yolk weight $(0.907$ and 0.905$)$, and yolk ratio (0.593 and 0.598), 
respectively. These results were agreed with Zita et al. [32], who found positive correlations of egg weight with yolk weight and albumen weight. Similarly, Minvielle et al. [33] detected positive correlations among egg weight, albumen weight and yolk weight.
Baumgartner et al. [34] mentioned that there was no significance in the correlations between egg weight and the yolk and albumen. On the contrary, Ozcelik [35] found a negative correlation between egg weight and yolk ratio.

Table 4: Correlation coefficients among the external and internal egg quality traits in Japanese quails.

\begin{tabular}{lcccccccc}
\hline & $\begin{array}{c}\text { Egg } \\
\text { Weight } \\
(\mathbf{g})\end{array}$ & $\begin{array}{c}\text { Egg } \\
\text { Surface } \\
\text { Area }\left(\mathbf{c m}^{2)}\right.\end{array}$ & $\begin{array}{c}\text { Egg } \\
\text { Width } \\
(\mathbf{m m})\end{array}$ & $\begin{array}{c}\text { Egg } \\
\text { Length } \\
(\mathbf{m m})\end{array}$ & $\begin{array}{c}\text { Egg shape } \\
\text { Index } \\
(\boldsymbol{\%})\end{array}$ & $\begin{array}{c}\text { Shell } \\
\text { Weight } \\
(\mathbf{g})\end{array}$ & $\begin{array}{c}\text { Shell } \\
\text { Ratio } \\
(\boldsymbol{\%})\end{array}$ & $\begin{array}{c}\text { Shell } \\
\text { Thickness } \\
(\mathbf{g})\end{array}$ \\
\cline { 2 - 9 } Albumin weight $(\mathbf{g})$ & $0.737^{* * * *}$ & $0.740^{* * * *}$ & $0.725^{* * * *}$ & $0.664^{* * *}$ & 0.125 & 0.333 & -0.229 & 0.143 \\
Albumin ratio (\%) & $-0.604^{* * *}$ & $-0.605^{* * *}$ & $-0.405^{* *}$ & -0.029 & $-0.490^{* * *}$ & -0.309 & 0.137 & -0.212 \\
Albumin height (mm) & -0.187 & -0.187 & -0.130 & -0.106 & -0.039 & $-0.377^{*}$ & -0.288 & -0.113 \\
Albumin width (mm) & 0.232 & 0.236 & 0.151 & 0.305 & -0.176 & 0.004 & -0.179 & -0.101 \\
Yolk weight (g) & $0.907^{* * *}$ & $0.905^{* * *}$ & $0.667^{* * *}$ & 0.301 & $0.498^{* * *}$ & 0.284 & $-0.402^{*}$ & 0.112 \\
Yolk ratio (\%) & $0.593^{* * *}$ & $0.598^{* * *}$ & $0.370^{*}$ & 0.147 & 0.303 & -0.112 & $-0.608^{* *}$ & -0.076 \\
Yolk height (mm) & 0.250 & 0.259 & $0.407^{*}$ & 0.328 & 0.123 & 0.102 & -0.120 & 0.212 \\
Yolk width (MM) & 0.292 & 0.307 & $0.444^{*}$ & $0.376^{*}$ & 0.117 & 0.438 & 0.248 & 0.387 \\
Haugh unit & $-0.542^{* * *}$ & $-0.542^{* * *}$ & $-0.432^{*}$ & 0.298 & -0.194 & $-0.512^{* *}$ & -0.151 & -0.194 \\
\hline
\end{tabular}

${ }^{*}$ significant at $\mathrm{P}<0.05, * *$ significant at $\mathrm{P}<0.01$ and $* * *$ significant at $\mathrm{P}<0.001$.

Egg weight and egg surface area were increased significantly $(\mathrm{P}<0.001)$ with the decrease in albumin ratio (-0.604) and Haugh unit (-0.542). Concretely, the correlation of the egg width with albumin weight and yolk weight was positive with significant differences $(\mathrm{P}<0.001)$, moreover, it was increased $(\mathrm{P}<0.05)$ with the increase in yolk ratio, height and its width. Nerveless, egg width was negatively correlated with albumin ratio (-0.405) and Haugh unit (-0.432). While, the length of the egg was correlated positively with albumin weight and yolk width. On the other hand, the egg shape index was positively correlated with yolk weight and negatively correlated with albumin ratio. These results were disagreed with Ozcelik [35], who noted a negative correlation between the egg shape index and yolk weight. Otherwise, the increase in shell weight was correlated with the decrease in albumin ratio (-0.377) and Haugh unit $(-0.512)$. The increase in shell ratio was followed by the decrease in yolk weight and its ratio. Kul and Seker [5] stated that albumen quality was correlated reversely with yolk and shell ratios.

\section{Conclusion}

In this study, housing Japanese quails at the different housing systems associated with significant differences in the most of egg quality and increased the most of the traits in cage system. Therefore, we can conclude that most of the egg quality (internal and external traits) were better in cage system and deep litter system with fine sawdust in comparison to the deep litter system with coarse sawdust.

\section{Conflict of interest}

The authors have no any conflict of interest.

\section{References}

[1] Punya Kumaril, B.; Ramesh Gupta, B.; Gnana Prakash, M. and Rajasekhar Reddy, A. (2008): A study of egg quality traits in Japanese quails. J Veterinary and Anim Sci, 4(6): 227-231.

[2] Shanaway, M. (1994): Quail production systems. A review. Animal production and health division, FAO, Rome, Italy.

[3] Mirjana, D.; Niko, M. and Lidija, P. (2012): Determining some exterior and interior quality traits of japanese quail eggs (coturnix japonica). Agroznanj, 13(4): 667-672. 
[4] EL-tarabany, S.; Tamer M. and Hesham H. (2015): Effects of cage stocking density on egg quality traits in Japanese Quail. Kafkas Univ Vet Fak Derg, 21(1): 13-18.

[5] Kul, S. and Seker, I. (2004): Phenotypic correlations between some external and internal egg quality traits in the Japanese Quail (Coturnix coturnix japonica). Int J Poult Sci, 3: 400-405.

[6] Olawumi, S. and Ogunalde, J. (2008): Phenotypic correlation between some external and internal egg quality traits in the exotic isa brown layer breeders. Asian J Poult Sci, 2: 30-35.

[7] Gihan, S. and Ensaf, A. (2012): Genetic analysis of clutch and some related production traits in Japanese quail. Egypt Poult Sci, 32: 443-456.

[8] Englmaierová, M.; Tůmová, E.; Charvátová, V. and Skřrivan, M. (2014): Effects of laying hens housing system on laying performance, egg quality characteristics, and egg microbial contamination. Czech J Anim Sci, 59(8): 345-352

[9] Van Den Brand, H.; Parmentier, H. and Kemp, B. (2004): Effects of housing system (outdoor vs. cages) and age of laying hens on egg characteristics. Brit Poult Sci, 45: 745-752.

[10] Hidalgo, A.; Rossi, M.; Clerici, F. and Ratti, S. (2008): A market study on the quality characteristics of eggs from different housing systems. Food Chem, 106: 1301-1308.

[11] Alam, M.; Abdur Rahman, M.; Mondal, A.; Hossain, K.; and Bostami, R. (2008): Pattern of egg production in Japanese quail reared on littered floor and in cage. Bang Res Public J, 1(3): 239-249.

[12] Arumugam, R.; Prabakaran, R.; and Silvakumar, T. (2014): Hatching performance of pure bred Japanese quail breeders under cage and deep litter systems of rearing. J Global Bio Sci, 3(7): 1105-1110.
[13] AOAC (2002): Official Methods of Analysis. Association official analytical chemists, Gaithersburg, USA.

[14] Ahmed, A.; Rodriguez-Navarro, A.; Vidal, M.; Gautron, J.; Garcia-Ruiz, J. and Nys, Y. (2005): Changes in eggshell mechanical properties, crystallographic texture and in matrix proteins induced by moult in hens. Brit Poult Sci, 46: 268279.

[15] Sezer, M. (2007): Heritability of exterior egg quality traits in Japanese quail. $\mathbf{J}$ App Bio Sci, 1: 37-40.

[16] Haugh, R. (1937): The Haugh unit for measuring egg quality. U.S. Egg Poult Mag, 43, 552-555, 572-573.

[17] SAS (2009): SAS statistical system Package-Jmp 8 User's Guide.2nd Cary, NC, SAS Institute Inc. USA.ISBN 9781-60764-301-2.

[18] Sokal, R. and Rohlf, F. (1969): Biometry: The principles and practice of statistics in biological research. San Francisco: W. H. Freeman. PP, 776.

[19] Bilgehan, Y.; Aydın, İ.; Umran, Ş.; Arda, S. and Süleyman, C. (2017): Impact of different housing systems and age of layers on egg quality characteristics. Turk J Vet Anim Sci, 41: 77-84.

[20] Leyendecker, M.; Hamann, H.; Hartung, J.; Kamphues, J.; Ring, C.; Glunder, G.; Ahlers, C.; Sander, I.; Neuman, U. and Distl, O. (2001): Analysis of genotype environment interactions between layer lines and housing systems for performance traits, egg quality and bone breaking strength: 2nd communication: egg quality traits. Zuchtungsk, 73: 308323.

[21] Pištěkova, V.; Hovorka, M.; Večerek, V.; Strakova, E. and Suchy, P. (2006): The quality comparison of eggs laid by laying hens kept in battery cages and in a deep litter system. Czech J Anim Sci, 51: 318325.

[22] Zemkova, L.; Simeonovova, J.; Lichovnikova, M. and Somerlikova, K. (2007): The effects of housing systems and age of hens on the weight and 
cholesterol concentration of the egg. Czech J Anim Sci, 52: 110-115.

[23] Şekeroğlu, A.; Sarıca, M.; Demir, E.; Ulutaş, A.; Tilki, M.; Saatci, $M$ and Omed, H. (2010): Effects of different housing systems on some performance traits and egg qualities of laying hens. J Anim Vet Adv, 9: 1739-1744.

[24] Jana, S.; Eva, T. and Michaela, E. (2014): The effect of housing system on egg quality of Lohmann white and Czech hen. Acta fytotechn. zootechn, 17(2): 4446.

[25] Ahammed, A.; Chae, B.; Lohakare, J.; Keohavong, B.; Lee, M.; Lee, S.; Kim, D.; Lee, J. and Ohh, S. (2014): Comparison of aviary, barn and conventional cage raising of chickens on laying performance and egg quality. Asian-Austral J Anim, 27: 1196-1203.

[26] Stojčić, M.; Perić, L.; Milošević, N.; Rodić, V.; Glamočić, D.; Škrbić, Z. and Lukić, M. (2012): Effect of genotype and housing system on egg production, egg quality and welfare of laying hens. J Food Agric Environ, 10: 556-559.

[27] Padmakumar, B.; Reghunanthan Nair, G.; Ramakrishnan, A.; Unni, A.K.K.; and Ravindranathan, N. (2000): Effect of floor space on egg weight and egg quality traits of Japanese quail raised in cages and deep litter. J Vet Anim Sci, 31: 37-39.

[28] El-Sheikh, T.; Essa, N.; Abdel-Kareem, A. and Elsagheer, M. (2016): Evaluation of productive and reproductive performance of japanese quails in floor pens and conventional cages with different stocking densities. Egypt Poult Sci, (36)(III): 669 -683.
[29] Samiullah, S.; Roberts, J. and Chousalkar, K. (2014): Effect of production system and flock age on egg quality and total bacterial load in commercial laying hens. J Appl Poult Res, 23: 59-70.

[30] Tůmova, E.; Englmaierova, M.; Ledvinka, Z. and Charvatova, V. (2011): Interaction between housing system and genotype in relation to internal and external egg quality parameters. Czech $\mathbf{J}$ Anim Sci, 56: 490-498.

[31] Abdel- Fatah, J. (2008): Changes in egg quality traits associated with long-term selection for lower yolk cholesterol content in Japanese quail. Czech J Anim Sci, 53: 119-127.

[32] Zita, L.; Ledvinka, Z. and Klesalová, L. (2013): The effect of the age of Japanese quails on certain egg quality traits and their relationships. Vet Arch, 83: 223232.

[33] Minvielle, F.; Monvoisin, J.; Costa, J. and Frenot, A. (1997): Quail lines selected for egg number based on pureline or crossbred performance. Proceedings of the 12th Symposium on Current Problems in Avian Genetics (Aviagen), Pruhonice (Czech Republic). PP. 99-103.

[34] Baumgartner, J.; Koncekova, J.; Benkova, J; Peskovicova, D.; Simenovova, J. and Scuka, J. (2008): Changes in egg quality traits associated with long-term selection for lower yolk cholesterol content in Japanese quail. Czech J Anim Sci, 53: 119-127.

[35] Ozcelik, M. (2002): The phenotypic correlations among some external and internal quality characteristics in Japanese quail eggs. Ankara Univ Vet Fak Derg, 49: 67-72. 


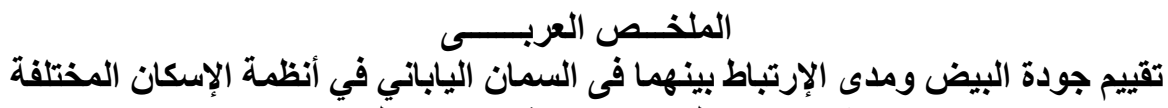

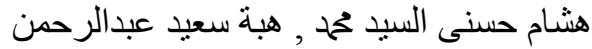 \\ قسم الصحة العامة البيطرية_ كلية الطب البيطري ـ جامعة الزقازيق}

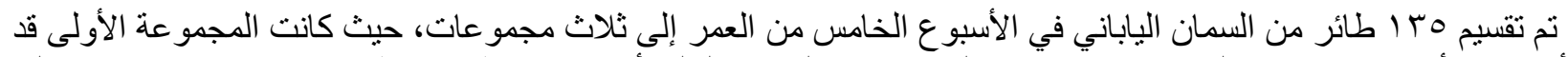

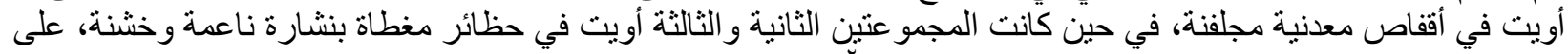

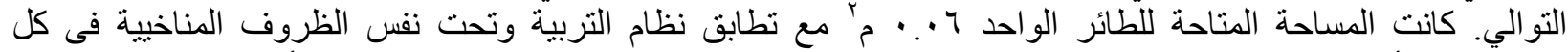

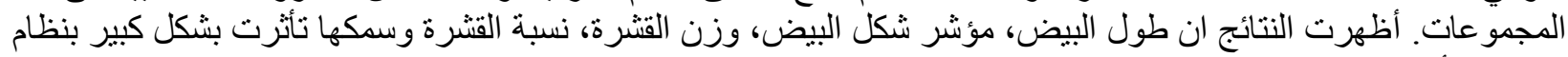

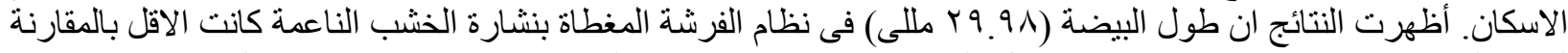

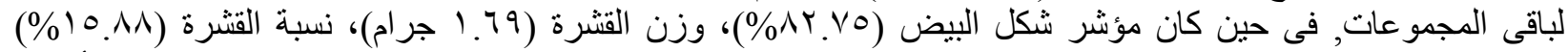

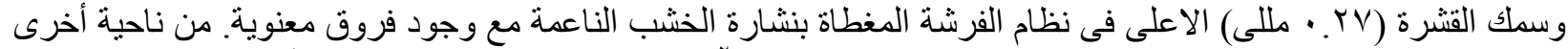

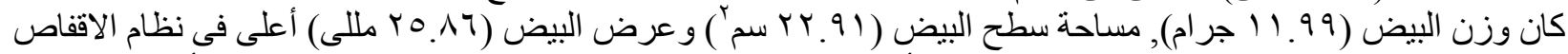

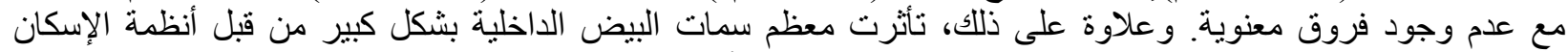

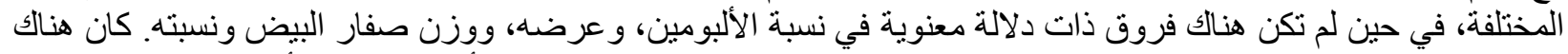

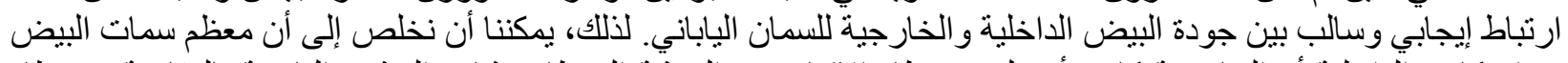

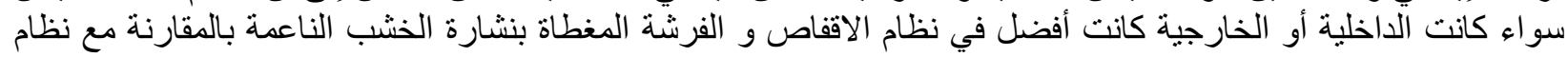
الفرشة المغطاة بنشارة الخشب الخشاء الخشنة. 